\title{
Determination of Heavy Metal Contamination in Soil and Accumulation in Cassava (Manihot Esculenta) in Automobile Waste Dumpsite at Ohiya Mechanic Village
}

\author{
Ogbonna P.C. ${ }^{1, *}$, Osim O.O. ${ }^{2}$ and Biose E. ${ }^{3}$ \\ ${ }^{1}$ Department of Environmental Management and Toxicology, Michael Okpara University of Agriculture, \\ Umudike, Abia State, Nigeria \\ ${ }^{2}$ Department of Geography, University of Nigeria, Nsukka, Enugu State, Nigeria \\ ${ }^{3}$ Department of Environmental Management and Toxicology, University of Benin, Edo State, Nigeria \\ *Corresponding Author: Ogbonna_princewill@yahoo.com
}

https://doi.org/10.36263/nijest.2020.01.0173

\begin{abstract}
Human health challenges resulting from consumption of food contaminated by heavy metals necessitated the investigation of soil and cassava plants around automobile waste dumpsite at Ohiya mechanic village, Abia State, Nigeria. Soil and cassava samples collected randomly at the site were analyzed for cadmium $(\mathrm{Cd})$, copper $(\mathrm{Cu})$, lead $(\mathrm{Pb})$ and chromium $(\mathrm{Cr})$. The values of highest concentration of $\mathrm{Cu}$ and $\mathrm{Pb}$ in soil was recorded in $0-10 \mathrm{~cm}, \mathrm{Cr}$ was obtained in 21-30 cm while Cd was in 11-20 cm soil depth. The concentration of $C d(0.11 \pm 0.00$ to $0.26 \pm 0.00 \mathrm{mg} / \mathrm{kg})$ in soil exceed maximum permitted level of $0.1 \mathrm{mg} / \mathrm{kg}(\mathrm{Cd})$ by $\mathrm{FAO} / \mathrm{WHO}$. The concentration of $\mathrm{Pb}(0.01 \pm 0.001$ to $3.24 \pm 0.00 \mathrm{mg} / \mathrm{kg})$ and $C d(0.07 \pm 0.00$ to $2.08 \pm 0.00 \mathrm{mg} / \mathrm{kg})$ in cassava plants exceed the permissible limit of $0.3 \mathrm{mg} / \mathrm{kg}(\mathrm{Pb})$ and $0.2 \mathrm{mg} / \mathrm{kg}(\mathrm{Cd})$ set by FAO/WHO. The Pearson correlation analysis show very strong positive relationship between $\mathrm{Cu}$ and $\mathrm{Cu}(r=0.996)$ and $\mathrm{Pb}$ and $\mathrm{Pb}(r=0.986)$ while strong negative relationship exist between $\mathrm{Cr}$ and $\mathrm{Cr}(r=-0.686)$ and $\mathrm{Cd}$ and $\mathrm{Cd}(r=-0.981)$ in soil and plant. Based on our findings, the concentrations of Cd in soil vis-à-vis Pb and Cd in plants which exceed maximum permitted level set by Codex Alimentarius Commission FAO/WHO will expose man and animals that relied on soil and cassava plants for food to serious health risks. Consequently, Abia State government should prevent farmers' access to the site by fencing round the automobile waste dumpsite.
\end{abstract}

Keywords: Automobile waste, dumpsite, heavy metals, soil, cassava plants, Ohiya

\subsection{Introduction}

The environment is continuously being contaminated by various human activities such as industrial production, agricultural processes, mineral exploitation, food processing, commercial, social, and domestic activities that generate contaminants like heavy metals (Ogbonna et al., 2018a). Continual loading of pollutants into the environment is of great concern to man since contaminants such as heavy metals persist in the environment due to its chemical structure (Ali et al., 2013; Hashem et al., 2017). Such contaminants include lead, cadmium, mercury and dioxin that never go away or degrade for long time. Over a long period of time, a large fraction of these contaminants may become buried in soil and even small residual amounts of these contaminants are a concern (Sakan and Dordevic, 2010).

Human health challenges in recent times have been attributed to consumption of food contaminated with heavy metals. Food contamination by human activities (Ogbonna et al., 2012; Ogbonna et al., 2013) is becoming very alarming due to quest to cope with high rate of food insecurity as well as other myriad of human needs in Nigeria. Cassava (Manihot esculenta Crantz) is considered the most essential staple root crop in the world and ranked as one of the most vital food crops grown in the tropics (Droppelmann et al., 2018; Olutosin and Barbara, 2019; Lawal et al., 2019). Besides playing a crucial 
role in food security, it is the cheapest source of industrial starch the world over (Zainuddin et al., 2019; Oyeyinka et al., 2019), alternative feedstock in many industrial applications like industrial baking flour, drug manufacturing, ethanol production among others due to its availability and low comparative cost (Anyanwu et al., 2015; Lawal et al., 2019). As a result of land hunger especially in the South east Nigeria, farmers are constrained to farming on lands adjoined to sources of pollution without considering the health implications of consuming crops grown on such lands (Ogbonna et al., 2018b). One of such adjoining sources of pollution is the mechanic village where automobile waste of various shapes, sizes and volumes are generated over a period of time (e.g. four years and above) and dumped at nearby lands. The corrosion of scrap metals as well as wear and tear due to rain (i.e. moisture) may release heavy metals into the soil. Plants growing on metal contaminated soil tend to absorb metals from soil solution via the roots and translocate it to the stems and the leaves (Ogbonna et al., 2018b). The use of plant parts is an effective indicator to monitor atmospheric pollution (Goodman and Robert 1971; Onder and Dursun 2006) but the distribution of heavy metals between soil and plants is a key issue in assessing the impact of anthropogenic activities, such as mechanic village on the ecosystem.

Quite a number of research on mechanic village or artisanal activities have been carried out in terms of heavy metal contamination in soil in Cape Coast metropolis, Ghana (Nyarko et al., 2019) Shashemane City, Ethiopia (Demie, 2015), Akure, Ondo State (Oguntimehin and Ipinmoroti, 2008), Imo river basin, Imo State (Nwachukwu et al., 2010), Gboko and Makurdi, Benue State (Pam et al., 2013; Luter et al., 2011), Anyigba, Kogi State (Ogunkolu et al., 2019), Abakaliki, Ebonyi State (Wilberforce, 2016), Port Harcourt, River State (Iwegbue et al., 2007), Okitipupa, Ondo State (Adebayo et al., 2017), Oghara, Delta State (Anegbe et al., 2018), Benin City, Edo State (Idugboe et al., 2014), soil and underground water (Owoso et al., 2017), soil and maize (Zea mays) Gwagwalada, Abuja (Okpanachi et al., 2016), pawpaw (Carica papaya Linn.) Port Harcourt metropolis, Rivers State (Eludoyin and Ogbe, 2017) in Nigeria. Despite the research, literature search show that no such work on heavy metal contamination of important root crop and staple food such as cassava has been carried out at any mechanic village site the world over. The objective of this study, therefore, is to investigate the level of concentrations of heavy metals in soil and their accumulation in cassava grown around automobile waste dumpsite at Ohiya mechanic village and compare the values with the maximum permissible limits of FAO/WHO, Dutch criteria for soil, the accepted limits of Federal Environmental Protection Agency (FEPA) and National Environmental Standards and Regulations Enforcement Agency (NESREA) of Nigeria. The results of this research will provide the background information on the levels of concentrations of heavy metals in the soil and plants and serve as an important document for proper dissemination of information to farmers by the Agricultural Development Programme (ADP), Abia State, thus, enhancing farmers knowledge on the possible health risk associated with farming on land in proximity with the mechanic village.

\subsection{Materials and Methods}

\subsection{Study area}

This study was carried out at the automobile waste dumpsite at Ohiya mechanic village in Umuahia South, Abia State, Nigeria. The Ohiya mechanic village was commissioned by the Abia State government on $6^{\text {th }}$ Novermber, 2014. Umuahia is the capital city of Abia State in Southeastern Nigeria and it has an area of $140 \mathrm{~km}^{2}$ and a population of 138,570 at the 2006 census (NPC, 2006). Ohiya is within the lowland rainforest zone of Nigeria (Keay, 1959; Ogbonna et al., 2018c) which lies on latitude $05^{\circ} 28^{\prime} \mathrm{N}$ and longitude $07^{\circ} 26^{\prime} \mathrm{E}$. The area has a mean annual rainfall of $2133 \mathrm{~mm}$ distributed over eight months of rainy season period (March to October) with bimodal peak in July and September. The soil is ultisol while the minimum and maximum temperature is $21^{\circ} \mathrm{C}$ and $30^{\circ} \mathrm{C}$ respectively, with relative humidity of $60-70 \%$. The main food crops grown by farmers include cassava, maize, yam, vegetables as fluted pumpkin, bitter leaf, okra; cash crops such as oil palm fruits, groundnuts among others. 


\subsection{Collection of samples and analysis}

Soil samples were collected with Dutch soil auger from nine (9) different sampling points $\left(A_{1}, A_{2}, A_{3}\right.$; $\mathrm{B}_{1}, \mathrm{~B}_{2}, \mathrm{~B}_{3}, \mathrm{C}_{1}, \mathrm{C}_{2}$, and $\mathrm{C}_{3}$ ) at 0 - 10, $11-20,21-30,31-40$ and $41-50 \mathrm{~cm}$ soil depth in three sampling positions (i.e. three sampling points each at entry point $\left(A_{1}, A_{2}\right.$ and $\left.A_{3}\right)$, middle point $\left(B_{1}, B_{2}\right.$ and $\left.B_{3}\right)$, and exit point $\left(\mathrm{C}_{1}, \mathrm{C}_{2}\right.$ and $\left.\left.\mathrm{C}_{3}\right)\right)$ of the $64 \mathrm{~m} \times 87 \mathrm{~m}$ dump site. The control sample was collected in an upland two (2) years bush fallow "at Uzo-Okpulo" which is about $1.5 \mathrm{~km}$ from the automobile waste dumpsite where there was no visible source of contamination. Samples from each particular soil depth (e.g., 0-10 $\mathrm{cm}$ at entry point, middle point and exit point) were bulked together to form a composite sample and were placed in cellophane bags (about $35 \mathrm{~g}$ ) well labelled, placed in a wooden box and covered to avoid contamination from external sources. The samples in the wooden box were transferred to the laboratory for pre-treatment and analysis. Each bulked soil sample was freed from foreign objects (roots, pebbles, etc.) and air-dried to a constant weight in an oven of $30^{\circ} \mathrm{C}$ with a circulating air. The samples were subjected to crushing, grinding and then homogenized using a porcelain pestle and mortar. The homogenized soil samples were sieved through a $2.0 \mathrm{~mm}$ sieve pore, giving rise to the actual workable samples, which were then placed in their labelled cellophane bags respectively and stored at room temperature for the next level of the analytical process (Garcia et al., 2004). Two ( $2 \mathrm{~g}$ ) of the dried samples each was weighed out into a digestion flask and added $20 \mathrm{ml}$ of the acid mixture $(650 \mathrm{ml}$ conc $\mathrm{HNO}_{3} ; 80 \mathrm{ml}$ perchloric acid; $20 \mathrm{ml}$ conc. $\mathrm{H}_{2} \mathrm{SO}_{4}$ ), then allowed for about $20 \mathrm{~min}$. The digestion flask containing the weighed out soil sample was heated until a clear digest is obtained. The clear digest was allowed to cool for $10 \mathrm{~min}$, filtered into $50 \mathrm{ml}$ standard flask with Whatman No. 41 filter paper, and then diluted with deionized water to the $100 \mathrm{ml}$ mark (Adrian, 1973) and analysed for $\mathrm{Pb}, \mathrm{Cd}, \mathrm{Cr}$, and $\mathrm{Cu}$. In order to check for background contamination by the reagents, blanks were prepared from only reagents without sample. Triplicate digestion of each sample was carried out. The digested samples were then subjected to analysis of heavy metals $(\mathrm{Pb}, \mathrm{Cd}, \mathrm{Cr}$, and $\mathrm{Cu})$ using the Atomic Absorption Spectrophotometer (Model: Perkin Elmer, USA).

Cassava samples for determination of heavy metals content was collected from fifteen (15) months old Cassava plant grown about $1 \mathrm{~m}$ away from the dumpsite. Control cassava samples were collected from a farmland about $1.5 \mathrm{~km}$ away from the experimental farmland where there was no visible source of contamination. Samples of cassava were collected randomly in the month of September from the $54 \mathrm{~m}$ x $72 \mathrm{~m}$ farmland, using well cleaned secateurs at various sampling points, three (3) points at each sampling positions (entry point (within $5 \mathrm{~m}$ from the dumpsite, middle point $(25 \mathrm{~m}$ away from the dumpsite) and exit point (50 m away from the dumpsite)) in the farmland. Samples were bulked together and separated into roots, stems and leaves, well labelled and transferred to the laboratory for pretreatment and analysis.

Samples were cleaned with deionized water to remove dust and debris after which they were oven-dried at $60^{\circ} \mathrm{C}$ for $72 \mathrm{hr}$. The roots, stems and leaves of the cassava plant samples were milled separately with Thomas Wiley milling machine to fine powder. The oven-dried, ground and sieved samples were accurately weighed and digested in a 1:1 mixture of concentrated nitric acid and perchloric acid (Oyelola et al., 2009). A $5 \mathrm{ml}$ of the mixture of concentrated nitric acid $\left(\mathrm{HNO}_{3}\right)$ and per chloric acid $\left(\mathrm{HCL}_{4}\right)$ was added to $2 \mathrm{~g}$ of each sample and heated on a hot plate at $105^{\circ} \mathrm{C}$ for an hour to dryness, allowed to cool for 10 mins, and then transferred to a volumetric flask. Exactly $1 \mathrm{M} \mathrm{HNO}_{3}$ was added to make up the solution to the mark of $50 \mathrm{ml}$ volumetric flask. The solution was centrifuged for $45 \mathrm{~min}$ and transferred to sampling bottles for analysis. In order to check for background contamination by the reagents, blanks were prepared from only reagents without sample. Triplicate digestion of each sample was carried out. The digested samples were then subjected to analysis of heavy metals ( $\mathrm{Pb}, \mathrm{Cd}, \mathrm{Cr}$, and $\mathrm{Cu}$ ) using the Atomic Absorption Spectrophotometer (Model: Perkin Elmer, USA). 


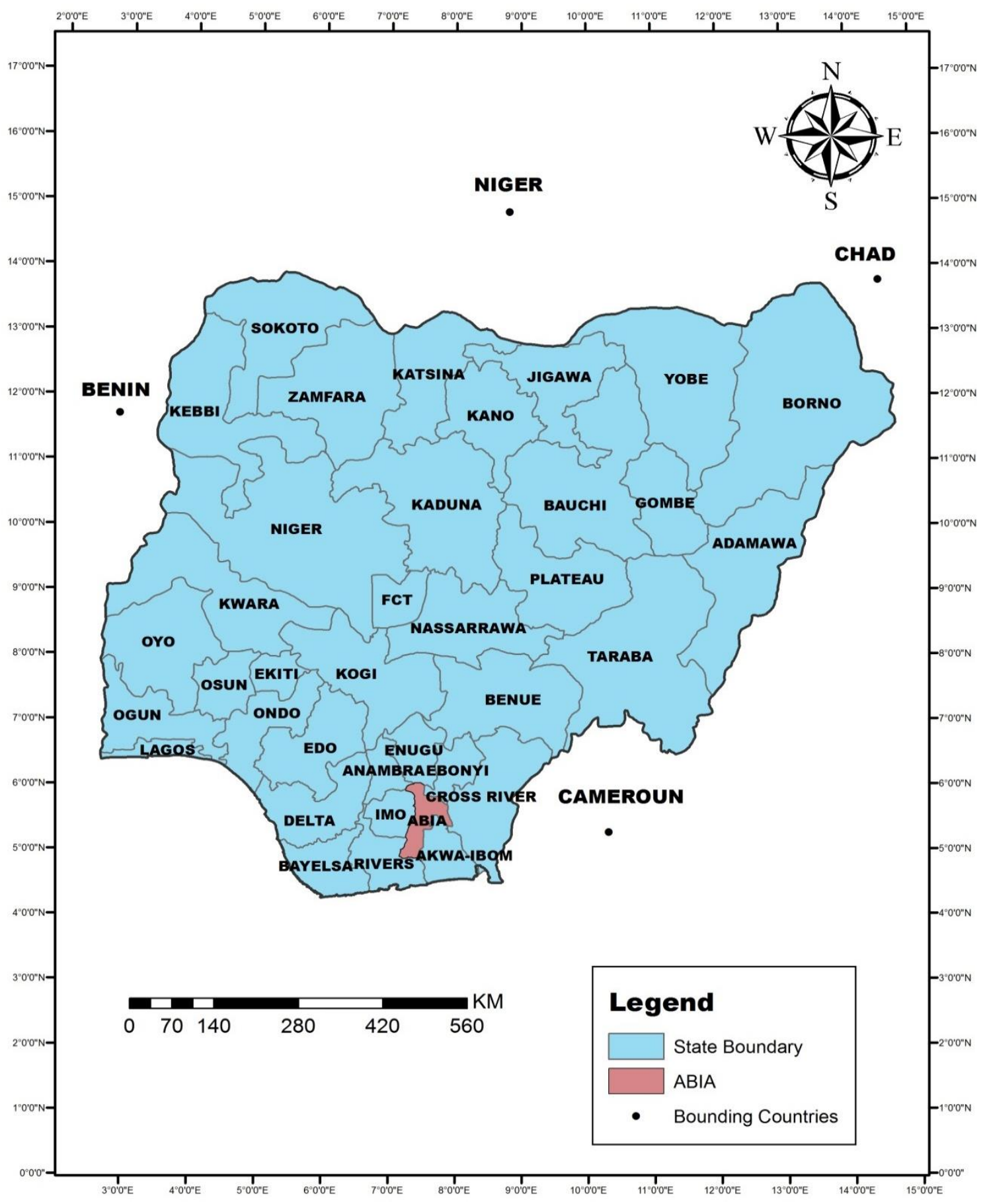

Figure 1: Map of Nigeria showing Abia State (Source: GIS Lab., Department of Geography, University of Nigeria, Nsukka (2018)) 


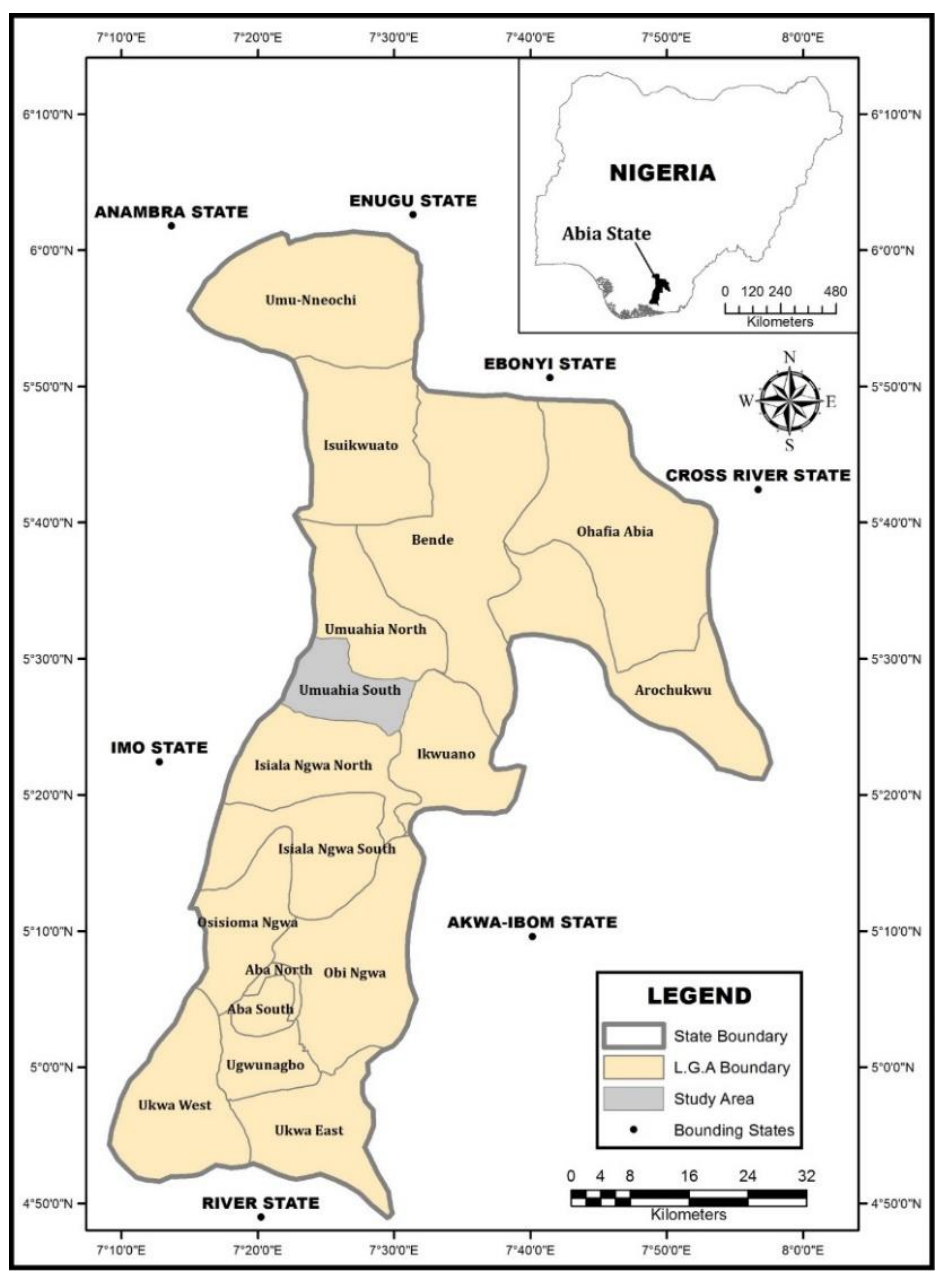

Figure 2: Abia State showing Umuahia South (Source: GIS Lab., Department of Geography, University of Nigeria, Nsukka (2018))

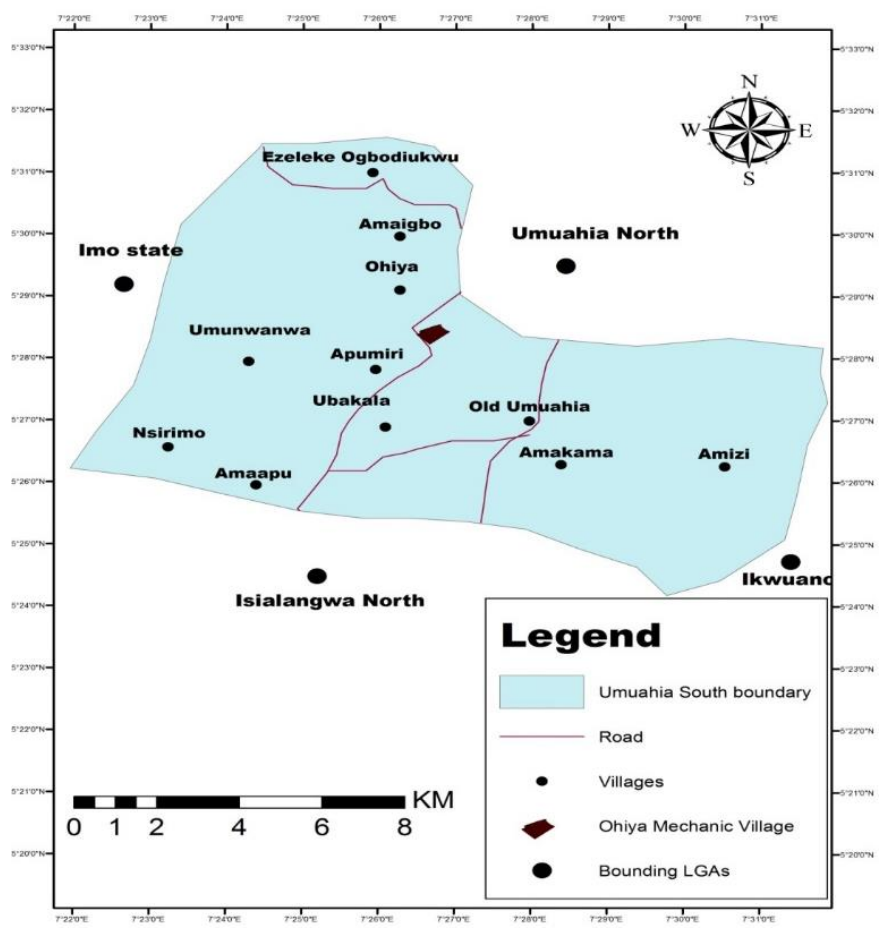

Figure 3: Map of Umuahia South LGA showing Umuahia mechanic village (Source: GIS Lab., Department of Geography, University of Nigeria, Nsukka (2018)) 


\subsection{Analysis of heavy metals}

Digested soil and plant samples was conducted using Agilent FS240AA Atomic Absorption Spectrophotometer according to the method of American Public Health Association, APHA (1995). Atomic absorption spectrophotometer's working principle is based on the sample being aspirated into the flame and atomized when the AAS's light beam is directed through the flame into the monochromator, and onto the detector that measures the amount of light absorbed by the atomized element in the flame. Some metals have their own characteristic absorption wavelength, a source lamp composed of that element is used, making the method relatively free from spectral or radiational interferences. The amount of energy of the characteristic wavelength absorbed in the flame is proportional to the concentration of the element in the sample. The instrument settings and operational conditions were in accordance with the manufacturer's specifications. The instrument was calibrated with analytical grade standard metal solutions.

\subsection{Statistical analysis and experimental design}

A simple factorial experiment was conducted in a randomized complete block design with five replications in soil depth. Data generated from the experiment were subjected to one way analysis of variance (ANOVA) using special package for social sciences (SPSS) v. 16 and means were separated (Steel and Torrie, 1980) at $\mathrm{P}<0.05$ using Duncan Multiple Range Test (DMRT) while Correlation analysis was used to determine the relationship between the means of the parameters analysed in soil and cassava plant.

The comparison and interpretation of the results of different parts of Manihot esculenta (cassava) analyzed in this study is based on the control values, the values of concentration of heavy metals in plants in similar studies, standards set by international agency such as Codex Alimentarius Commission as well as national agencies such as Federal Environmental Protection Agency (FEPA) and National Environmental Standards and Regulations Enforcement Agency (NESREA) of Nigeria.

\subsection{Results and Discussion}

\subsection{Concentration of heavy metals in soil}

The values of the concentration of heavy metals in the different soil depths in automobile waste dumpsite at Ohiya mechanic village are summarized in Table 1. Heavy metal concentration in soil in this study were raised to different levels and the significant differences was evidenced amongst the different soil depths at study site. The various anthropogenic activities such as panel beating, servicing of car engines and changing of electrical component of vehicles among other resulted to generation of heavy metal contaminated materials that are discarded at the dumpsite. The results indicate that the highest and lowest heavy metal concentrations in soil were obtained at the scrap metal dumpsite and control site, respectively for $\mathrm{Cd}, \mathrm{Pb}, \mathrm{Cu}$ and $\mathrm{Cr}$. Some pollution surveys showed that soil within or around source of pollutants had high concentrations of heavy metals (Davila et al., 2006; Nwachukwu et al., 2010; Ogbonna et al., 2013; Ogbonna et al., 2018a). Since there were no other sources of contamination in the area, the high concentrations of heavy metals in soil of the automobile waste dumpsite (unlike the control) may be attributed to leaching of the heavy metals $(\mathrm{Cd}, \mathrm{Pb}, \mathrm{Cu}$ and $\mathrm{Cr}$ ) from the large volume of waste from Ohiya mechanic village waste dumpsite.

The concentration of heavy metals was observed to peak within 21-30 cm depth for Cr while Cd had its concentration within 11-20 and 21-30 cm depths unlike $\mathrm{Cu}$ and $\mathrm{Pb}$ that had their highest concentrations in $0-10 \mathrm{~cm}$ depth. The pattern of leaching or migration of heavy metals in the soil suggest that $\mathrm{Cr}$ and $\mathrm{Cd}$ were relatively more mobile than $\mathrm{Pb}$ and $\mathrm{Cu}$ at the study site. Cadmium is known to be highly mobile in soil (Ogbonna and Okeke, 2011) and its mobility at the automobile waste dumpsite peaked within 11-20 and 21-30 cm depths. The high concentrations of $\mathrm{Pb}$ and $\mathrm{Cu}$ in $0-10 \mathrm{~cm}$ depth may be attributed to presence of organic matter since heavy metals are bound to topsoil by organic matter (Sukkariyah $e t$ 
al., 2005) hence reducing the leaching of heavy metals into the lower depths (Ogbonna et al., 2018b). Organic matter waste residue from effluent oil and oil spills adds organic matter and carbon to the soil (Anegbe et al., 2018).

The highest concentration of $\mathrm{Cd}(0.26 \pm 0.00 \mathrm{mg} / \mathrm{kg})$ was jointly recorded in $11-20$ and $21-30 \mathrm{~cm}$ depths, and the value is significantly $(\mathrm{P}<0.05)$ higher than values observed for $\mathrm{Cd}$ in $0-10 \mathrm{~cm}(0.3 \pm 0.00 \mathrm{mg} / \mathrm{kg})$, $31-40 \mathrm{~cm}(0.20 \pm 0.00 \mathrm{mg} / \mathrm{kg}), 41-50 \mathrm{~cm}(0.11 \pm 0.00 \mathrm{mg} / \mathrm{kg})$ and control $(0.16 \pm 0.03,0.15 \pm 0.01$, $0.05 \pm 0.00,0.02 \pm 0.00$ and $0.00 \pm 0.00 \mathrm{mg} / \mathrm{kg}$, respectively for $0-10,11-20,21-30,31-40$ and $41-50 \mathrm{~cm}$ ). The heavy metals from the scrap metal at the dumpsite may have provided a source for continued dispersion and have resulted to various degree of contamination of $\mathrm{Cd}$ in the soil depths. For instance, Ogbonna and Okezie (2011) in their study of roadside soils reported that $\mathrm{Cd}$ is released from the wearing of paints on the metal parts of vehicles. The values of the concentration of $\mathrm{Cd}$ in automobile waste dumpsite soils of Ohiya mechanic village was $0.11 \pm 0.00$ to $0.26 \pm 0.00 \mathrm{mg} / \mathrm{kg}$, which is well below 31.5 to $47.5 \mathrm{mg} / \mathrm{kg}$ (Nwachukwu et al., 2010), 26.0 to $48.0 \mathrm{mg} / \mathrm{kg}$ (Iwegbue et al., 2007), 19.86 to 21.421 $\mathrm{mg} / \mathrm{kg}$ (Idugboe et al., 2014) and 0.87 to $2.55 \mathrm{mg} / \mathrm{kg}$ (Anegbe et al., 2018) but higher than 0.01 to 0.12 $\mathrm{mg} / \mathrm{kg}$ (Adebayo et al., 2017) in their studies of heavy metals in soils. The low concentration of Cd in soils of Ohiya mechanic village may be attributed to short period of time of its existence (i.e. 015 till date) as well as the type and volume of waste at the automobile dumpsite. Nwachukwu et al. (2010) opined that the type of automobile waste at dumpsite, volume of waste and length of time the dump has been in use influence the release of metals. The concentration of $\mathrm{Cd}(0.26 \pm 0.00 \mathrm{mg} / \mathrm{kg})$ in $11-20$ and 21-30 cm depth was found to be 1.13, 1.30, 2.36 times higher than its values in 0-10, 31-40 and 41-50 $\mathrm{cm}$ at the dumpsite and 1.63, 1.73, 5.2, 13 and 26 times higher than 0-10, 11-20, 21-30, 31-40 and 41$50 \mathrm{~cm}$ at the control site, respectively.

The highest concentration of $\mathrm{Pb}(2.57 \pm 0.00 \mathrm{mg} / \mathrm{kg})$ and $\mathrm{Cu}(1.28 \pm 0.00 \mathrm{mg} / \mathrm{kg})$ were recorded in $0-10$ $\mathrm{cm}$ depth and the values are significantly $(\mathrm{P}<0.05)$ higher than their corresponding values in $11-20 \mathrm{~cm}$ $(1.34 \pm 0.00$ and $0.50 \pm 0.00 \mathrm{mg} / \mathrm{kg}), 21-30 \mathrm{~cm}(1.92 \pm 0.00$ and $0.57 \pm 0.00 \mathrm{mg} / \mathrm{kg}), 31-40 \mathrm{~cm}(0.93 \pm 0.00$ and $0.27 \pm 0.00 \mathrm{mg} / \mathrm{kg}), 41-50 \mathrm{~cm}(0.93 \pm 0.00$ and $0.41 \pm 0.00 \mathrm{mg} / \mathrm{kg})$ and control $(1.36 \pm 0.01$ and $1.03 \pm 0.01,0.59 \pm 0.00$ and $0.01 \pm 0.00,0.79 \pm 0.00$ and $0.32 \pm 0.02,0.31 \pm 0.01$ and $0.03 \pm 0.00,0.23 \pm 0.02$, and $0.01 \pm 0.00 \mathrm{mg} / \mathrm{kg}$, respectively for $\mathrm{Pb}$ and $\mathrm{Cu}$ in $0-10,11-20,21-30,31-40$ and $41-50 \mathrm{~cm}$ depths). The concentration of $\mathrm{Pb}$ in soil may be attributed to lead-acid batteries, adhesion of lead halides from petroleum motor spirit (PMS) and spent lubricating oil used for cleaning engines and other vehicular parts during servicing and are discarded at the automobile dumpsite. Lead $(\mathrm{Pb})$ is part of the composition of lubricating oil and galvanized parts of vehicles (Falahi-Ardakani, 1984; Zechmeister et al., 2005). It $(\mathrm{Pb})$ is also released from babbit metal bushings (Oguntimehin and Ipinmoroti, 2008) that are discarded at automobile waste dumpsite in Ohiya mechanic village. The concentration of $\mathrm{Pb}$ in $0-10 \mathrm{~cm}$ depth $(2.57 \pm 0.00 \mathrm{mg} / \mathrm{kg})$ was found to be $1.92,1.34,2.76$ times higher than its corresponding values in 11$20,21-30,31-40,41-50 \mathrm{~cm}$ depth at the study site and 1.89, 4.36, 3.25, 8.29 and 11.7 times higher than its values in $0-10,11-20,21-30,31-40$ and $41-50 \mathrm{~cm}$ depths at the control site, respectively. The concentration of $\mathrm{Pb}$ in soils of the automobile dumpsite at Ohiya mechanic village was $0.93 \pm 0.00$ to $2.57 \pm 0.00 \mathrm{mg} / \mathrm{kg}$, which is higher than 0.01 to $0.80 \mathrm{mg} / \mathrm{kg}$ (Adebayo et al., 2017) but well below $283.7 \pm 127$ to $665 \pm 912 \mathrm{mg} / \mathrm{kg}$ (Pam et al., 2013), $0.055 \pm 0.008$ to $21,200 \pm 90 \mathrm{mg} / \mathrm{kg}$ (Owoso et al., 2017), 18.25 to $15,100 \mathrm{mg} / \mathrm{kg}$ (Adelekan and Abegunde, 2011), $268.12 \pm 46.8$ to $664.62 \pm 52 \mathrm{mg} / \mathrm{kg}$ (Wilberforce et al., 2016) and 1.66 to $172.76 \mathrm{mg} / \mathrm{kg}$ (Luter et al., 2011).

The high concentration of $\mathrm{Cu}$ in soil at the dumpsite (unlike the control plot) may be attributed to presence of car brake and metal bearing at the automobile waste dumpsite. Copper is included in car brake (Falahi-Ardakani, 1984) and metal bearing (Oguntimehin and Ipinmoroti, 2008) which are gradually released and leached into the soil at the Ohiya mechanic village dumpsite. Copper in soil may also be attributed to automobile wastes containing electrical and electronic parts like copper wires and pipes, electrodes and alloys from corroding vehicle scraps (Pam et al., 2013) that are leached into the soil (Nwachukwu et al., 2011; Adebayo et al., 2017). The concentration of $\mathrm{Cu}$ in soils of Ohiya mechanic village was $0.41 \pm 0.00$ to $1.28 \pm 0.00 \mathrm{mg} / \mathrm{kg}$, which is well below 375 to $1,281 \mathrm{mg} / \mathrm{kg}$ (Nwachukwu et al., 2010), 28.26 to $44.35 \mathrm{mg} / \mathrm{kg}$ (Anegbe et al., 2018), 16.270 to $22.83 \mathrm{mg} / \mathrm{kg}$ (Idugboe 
et al., 2014) and 210 to $630.1 \mathrm{mg} / \mathrm{kg}$ (Adebayo et al., 2017) in their studies of heavy metals in soils of mechanic villages. The concentration of $\mathrm{Cu}$ in $0-10 \mathrm{~cm}(1.28 \pm 0.00 \mathrm{mg} / \mathrm{kg})$ was found to be $2.56,2.25$, 4.74 and 3.12 times higher than its corresponding values in 11-20, 21-30, 31-40 and 41-50 cm depth at the study site and 1.24, 128, 4, 42.67 and 128 times higher than its values in 0-10, 11-20, 21-30, 31-40 and $41-50 \mathrm{~cm}$ depth at the control site, respectively.

Table 1: Heavy metals concentration $(\mathrm{mg} / \mathrm{kg})$ in soil

\begin{tabular}{ccccc}
\hline Soil depths $(\mathrm{cm})$ & $\mathrm{Cr}$ & $\mathrm{Cu}$ & $\mathrm{Pb}$ & $\mathrm{Cd}$ \\
\hline $0-10$ & $0.01^{\mathrm{e}} \pm 0.00$ & $1.28^{\mathrm{a}} \pm 0.00$ & $2.57^{\mathrm{a}} \pm 0.00$ & $0.23^{\mathrm{b}} \pm 0.00$ \\
$11-20$ & $0.05^{\mathrm{c}} \pm 0.00$ & $0.50^{\mathrm{d}} \pm 0.00$ & $1.34^{\mathrm{c}} \pm 0.00$ & $0.26^{\mathrm{a}} \pm 0.00$ \\
$21-30$ & $0.13^{\mathrm{a}} \pm 0.00$ & $0.57^{\mathrm{c}} \pm 0.00$ & $1.92^{\mathrm{b}} \pm 0.00$ & $0.26^{\mathrm{a}} \pm 0.00$ \\
$31-40$ & $0.04^{\mathrm{cd}} \pm 0.00$ & $0.27^{\mathrm{g}} \pm 0.00$ & $0.93^{\mathrm{d}} \pm 0.00$ & $0.20^{\mathrm{c}} \pm 0.00$ \\
$41-50$ & $0.08^{\mathrm{b}} \pm 0.00$ & $0.41^{\mathrm{e}} \pm 0.00$ & $0.93^{\mathrm{d}} \pm 0.00$ & $0.11^{\mathrm{f}} \pm 0.00$ \\
C. $0-10$ & $0.00^{\mathrm{f}} \pm 0.00$ & $1.03^{\mathrm{b}} \pm 0.01$ & $1.36^{\mathrm{c}} \pm 0.01$ & $0.16^{\mathrm{d}} \pm 0.03$ \\
C. $11-20$ & $0.03^{\mathrm{d}} \pm 0.01$ & $0.01^{\mathrm{i}} \pm 0.00$ & $0.59^{\mathrm{f}} \pm 0.00$ & $0.15^{\mathrm{e}} \pm 0.01$ \\
C. $21-30$ & $0.11^{\mathrm{ab}} \pm 0.02$ & $0.32^{\mathrm{f}} \pm 0.02$ & $0.79^{\mathrm{e}} \pm 0.00$ & $0.05^{\mathrm{g}} \pm 0.00$ \\
C. $31-40$ & $0.01^{\mathrm{e}} \pm 0.00$ & $0.03^{\mathrm{h}} \pm 0.00$ & $0.31^{\mathrm{g}} \pm 0.01$ & $0.02^{\mathrm{h}} \pm 0.00$ \\
C. $41-50$ & $0.03^{\mathrm{d}} \pm 0.00$ & $0.01^{\mathrm{i}} \pm 0.00$ & $0.23^{\mathrm{h}} \pm 0.02$ & $0.00^{\mathrm{i}} \pm 0.00$
\end{tabular}

Note: Values are mean \pm standard deviation of 3 replicates; ${ }^{a, b, c, d, e f, g, h, i}$ means in the same column with different superscripts are significantly different $(P<0.05)$ and $C=$ mean of the Control plot

Table 2: Comparison with international and national standards

\begin{tabular}{lcccc}
\hline Source & $\mathrm{Cr}$ & $\mathrm{Cu}$ & $\mathrm{Pb}$ & $\mathrm{Cd}$ \\
\hline This study & $0.01-0.13$ & $0.41-1.28$ & $0.93-2.57$ & $0.11-0.06$ \\
Dutch criteria (target value), mg/kg & 100 & 36 & 85 & 0.8 \\
FAO/WHO 2001, 2006, 2007 & 100 & 100 & 50 & 0.1 \\
FEPA 1999 & $\mathrm{NA}$ & $70-80$ & 1.6 & 0.01 \\
NESREA 2011 standard, mg/kg & 100 & 100 & $\mathrm{NA}$ & 3 \\
*UK & 400 & 135 & 300 & 3 \\
*Netherlands & 30 & 40 & 40 & 0.5 \\
*France & 150 & 100 & 100 & 2 \\
*Sweden & 60 & 40 & 40 & 0.4 \\
\hline
\end{tabular}

*Source: ECDGE (2010); NA = Not available

The highest concentration of $\mathrm{Cr}(0.13 \pm 0.00 \mathrm{mg} / \mathrm{kg})$ was recorded for $21-30 \mathrm{~cm}$ depth and the value is significantly $(\mathrm{P}<0.05)$ higher than values recorded for $\mathrm{Cr}$ in $0-10 \mathrm{~cm}(0.01 \pm 0.00 \mathrm{mg} / \mathrm{kg}), 11-20 \mathrm{~cm}$ $(0.05 \pm 0.00 \mathrm{mg} / \mathrm{kg}), 31-40 \mathrm{~cm}(0.04 \pm 0.00 \mathrm{mg} / \mathrm{kg}), 41-50 \mathrm{~cm}(0.08 \pm 0.00 \mathrm{mg} / \mathrm{kg})$ and control $(0.00 \pm 0.00$, $0.03 \pm 0.01,0.11 \pm 0.02,0.01 \pm 0.00$ and $0.03 \pm 0.00 \mathrm{mg} / \mathrm{kg}$, respectively for $\mathrm{Cr}$ in $0-10,11-0,21-30,31-40$ and $41-50 \mathrm{~cm}$ depths). The concentration of $\mathrm{Cr}$ in $21-30 \mathrm{~cm}$ depth $(0.13 \pm 0.00 \mathrm{mg} / \mathrm{kg})$ was found to be $13,2.6,3.25$ and 1.63 times higher than its corresponding values in $0-10,11-20,31-40$ and $41-50 \mathrm{~cm}$ depths at the automobile waste dumpsite and 13, 4.33, 1.18, 13 and 13 times higher than its values in 0-10, 11-20, 21-30, 31-40 and 41-50 cm depth at the control site, respectively. The concentration of $\mathrm{Cr}$ in soils of the automobile waste dump at Ohiya mechanic village was $0.01 \pm 0.00$ to $0.13 \pm 0.00 \mathrm{mg} / \mathrm{kg}$, which is well below 3.313 to $9.92 \mathrm{mg} / \mathrm{kg}$ (Idugboe et al., 2014), $1.14 \pm 0.12$ to $6.18 \pm 0.18 \mathrm{mg} / \mathrm{kg}$ (Wilberforce et al., 2016), 40.98 to $57.28 \mathrm{mg} / \mathrm{kg}$ (Luter et al., 2016), $0.219 \pm 0.003$ to $4,850 \pm 17 \mathrm{mg} / \mathrm{kg}$ (Owoso et al., 2017), 2.00 to $29.75 \mathrm{mg} / \mathrm{kg}$ (Adelekan and Abegunde, 2011), 6.98 to $21.10 \mathrm{mg} / \mathrm{kg}$ (Iwegbue et al., 2007), 16.8 to $38 \mathrm{mg} / \mathrm{kg}$ (Nwachukwu et al., 2010) and 0.01 to $0.42 \mathrm{mg} / \mathrm{kg}$ (Adebayo et al., 2017). In this study, it was observed that the highest value of $\mathrm{Cr}$ at the control site was obtained in $21-30 \mathrm{~cm}$ depth $(0.11 \pm 0.02 \mathrm{mg} / \mathrm{kg})$, which is similar to the highest value $(0.13 \pm 0.00 \mathrm{mg} / \mathrm{kg})$ obtained in soils at the automobile waste dumpsite. This indicate that the level of $\mathrm{Cr}$ in soil may be attributed to natural processes rather than anthropogenic activities at the mechanic village. 
The concentration of $\mathrm{Pb}, \mathrm{Cu}$, and $\mathrm{Cr}$ in automobile waste dumpsite soils of Ohiya mechanic village in Umuahia south, Abia State, Nigeria were $0.93 \pm 0.00$ to $2.57 \pm 0.00,0.41 \pm 0.00$ to $1.28 \pm 0.00$ and $0.01 \pm 0.00$ to $0.13 \pm 0.00 \mathrm{mg} / \mathrm{kg}$, respectively, which are well below the accepted limits (i.e. target value) and maximum permitted levels of 85 and $50 \mathrm{mg} / \mathrm{kg}(\mathrm{Pb}), 36$ and $100 \mathrm{mg} / \mathrm{kg}(\mathrm{Cu})$ as well as 100 and $100 \mathrm{mg} / \mathrm{kg}(\mathrm{Cr})$ as described by Dutch criteria (Ogbonna et al., 2018b) and established by the Codex Alimentarius Commission (FAO/WHO, 2001) (Table 2), respectively. Similarly, the concentrations of $\mathrm{Cu}(0.41 \pm 0.00$ to $1.28 \pm 0.00 \mathrm{mg} / \mathrm{kg})$ and $\mathrm{Cr}(0.01 \pm 0.00$ to $0.13 \pm 0.00 \mathrm{mg} / \mathrm{kg})$ in this study are well below the accepted limits of 100 and $100 \mathrm{mg} / \mathrm{kg}$ as described by National Environmental Standards and Regulations Enforcement Agency (NESREA, 2001) of Nigeria for $\mathrm{Cu}$ and $\mathrm{Cr}$, respectively. However, the concentration of $\mathrm{Cd}(0.11 \pm 0.00$ to $0.26 \pm 0.00 \mathrm{mg} / \mathrm{kg})$ in soil at the automobile waste dumpsite is above the maximum permitted level of $0.1 \mathrm{mg} / \mathrm{kg}(\mathrm{Cd})$ established by the Codex Alimentarius Commission (FAO/WHO, 2001) and $0.01 \mathrm{mg} / \mathrm{kg}(\mathrm{Cd})$ set by the Federal Environmental Protection Agency (FEPA, 1991) of Nigeria. The level of Cd in soils at the automobile waste dumpsite can pose a serious health risk to living organisms. For instance, earthworms are important bait in fishing as well as food material for fish production in south eastern Nigeria (Ogbonna et al., 2013; Ogbonna et al., 2019), prey to many amphibian, reptile, bird, and mammalian species (OECD, 2004). Hence, heavy metal pollution of earthworm at the study site can trigger death of animals living within and around the vicinity of the automobile waste dumpsite of Ohiya mechanic village, inter alia, decimation of fauna species along the food chain. It can also lead to decline in ecological processes taken place at the site since earthworm plays vital role in organic matter decomposition. The order of abundance of the four (4) heavy metals tested in this study that may be causing soil pollution within and around the automobile waste dumpsite at Ohiya mechanic village are as follows: $\mathrm{Pb}>\mathrm{Cu}>\mathrm{Cd}>\mathrm{Cr}$.

\subsection{Concentration of heavy metals in cassava plants}

The concentration of four (4) heavy metals in different parts of Manihot esculenta sampled from the automobile waste dumpsite and control site of Ohiya mechanic village, Umuahia south are summarized in Table 3. The results indicate that heavy metal concentrations differed significantly $(\mathrm{P}<0.05)$ among the different parts of Manihot esculenta tested in this study and that the highest and the lowest heavy metal concentrations in cassava plants were recorded for the automobile waste dumpsite and control site, respectively. The highest values of $\mathrm{Cr}(0.051 \pm 0.002 \mathrm{mg} / \mathrm{kg}), \mathrm{Cu}(4.01 \pm 0.00 \mathrm{mg} / \mathrm{kg}), \mathrm{Pb}(2.08 \pm 0.00$ $\mathrm{mg} / \mathrm{kg})$ and $\mathrm{Cd}(3.24 \pm 0.00 \mathrm{mg} / \mathrm{kg})$ recorded in cassava root sampled at the automobile waste dumpsite were significantly $(\mathrm{P}<0.05)$ higher than the highest corresponding values of $\mathrm{Cr}(0.011 \pm 0.002 \mathrm{mg} / \mathrm{kg}$ in stem), $\mathrm{Cu}(1.01 \pm 0.002 \mathrm{mg} / \mathrm{kg}$ in root), $\mathrm{Pb}(1.12 \pm 0.002 \mathrm{mg} / \mathrm{kg}$ in root) and $\mathrm{Cd}(1.00 \pm 0.002 \mathrm{mg} / \mathrm{kg})$ in root) at the control site. The highest values of $\mathrm{Cr}, \mathrm{Cu}, \mathrm{Pb}$ and $\mathrm{Cd}$ in $M$. esculenta collected from the automobile waste dumpsite exceeded their corresponding values at the control site by 4.64, 3.97, 1.86 and 3.24 times, respectively. The result corroborates with the findings of Okpanachi et al. (2016) and Eludoyin and Ogbe (2017) who reported that the concentration of heavy metals in plants at mechanic workshops and village is higher than the concentration in plants at the control sites.

The concentration of $\mathrm{Pb}$ was $0.07 \pm 0.000$ (stem) to $2.08 \pm 0.00 \mathrm{mg} / \mathrm{kg}$ (root), which is well below $5.48 \pm$ to $33.28 \mathrm{mg} / \mathrm{kg}$ in maize plant (Okpanachi et al., 2016) and 18.40 to $80.30 \mathrm{mg} / \mathrm{kg}$ in pawpaw plant (Eludoyin and Ogbe, 2017) at mechanic workshop and village, respectively. The concentration of Cd was $0.01 \pm 0.001$ (stem) to $3.24 \pm 0.00 \mathrm{mg} / \mathrm{kg}$ (root) and this is well below 1.75 to $10.56 \mathrm{mg} / \mathrm{kg}$ in maize plant (Okpanachi et al., 2016) and 2.3 to $18.0 \mathrm{mg} / \mathrm{kg}$ in pawpaw plant (Eludoyin and Ogbe, 2016). Similarly, the values of the concentration of $\mathrm{Cu}$ was $0.01 \pm 0.000$ (leaf) to $4.01 \pm 0.00 \mathrm{mg} / \mathrm{kg}$ (root), which is well below 25.38 to $79.42 \mathrm{mg} / \mathrm{kg}$ in maize (Okpanachi et al., 2016) and 15.6 to $88.0 \mathrm{mg} / \mathrm{kg}$ in pawpaw (Eludoyin and Ogbe, 2017) while the values of the concentration of $\mathrm{Cr}$ was $0.001 \pm 0.000$ (root) to $0.051 \pm 0.002 \mathrm{mg} / \mathrm{kg}$ (root). The low values of the concentration of $\mathrm{Pb}, \mathrm{Cd}, \mathrm{Cu}$ and $\mathrm{Cr}$ in this study may be attributed to the short length of time the automobile waste dumpsite at Ohiya mechanic village has been in use. 
Table 3: Means and Standard deviation of heavy metals content $(\mathrm{mg} / \mathrm{kg})$ in Manihot esculenta

\begin{tabular}{lcccc}
\hline Plant parts & $\mathrm{Cr}$ & $\mathrm{Cu}$ & $\mathrm{Pb}$ & $\mathrm{Cd}$ \\
\hline Root & $0.051^{\mathrm{a}} \pm 0.002$ & $4.01^{\mathrm{a}} \pm 0.00$ & $2.08^{\mathrm{a}} \pm 0.00$ & $3.24^{\mathrm{a}} \pm 0.00$ \\
Stem & $0.018^{\mathrm{b}} \pm 0.001$ & $0.17^{\mathrm{c}} \pm 0.00$ & $0.82^{\mathrm{d}} \pm 0.00$ & $0.21^{\mathrm{c}} \pm 0.00$ \\
Leaf & $0.020^{\mathrm{b}} \pm 0.001$ & $0.10^{\mathrm{d}} \pm 0.00$ & $1.23^{\mathrm{b}} \pm 0.00$ & $0.20^{\mathrm{c}} \pm 0.00$ \\
C. Root & $0.001^{\mathrm{e}} \pm 0.000$ & $1.01^{\mathrm{b}} \pm 0.002$ & $1.12^{\mathrm{c}} \pm 0.002$ & $1.001^{\mathrm{b}} \pm 0.002$ \\
C. Stem & $0.011^{\mathrm{c}} \pm 0.002$ & $0.03^{\mathrm{e}} \pm 0.000$ & $0.07^{\mathrm{e}} \pm 0.000$ & $0.01^{\mathrm{f}} \pm 0.001$ \\
C. Leaf & $0.002^{\mathrm{d}} \pm 0.001$ & $0.01^{\mathrm{f}} \pm 0.000$ & $072^{\mathrm{e}} \pm 0.001$ & $0.02^{\mathrm{e}} \pm 0.001$ \\
\hline
\end{tabular}

Values are mean \pm standard deviation of 3 replicates; ${ }^{a, b, c, d, e, f, g, h, i}$ Means in the same column with different superscripts are significantly different $(P<0.05)$ and $C=$ mean of the Control plot

Table 4: Comparison with international and national standards

\begin{tabular}{lcccc}
\hline Source & $\mathrm{Cr}$ & $\mathrm{Cu}$ & $\mathrm{Pb}$ & $\mathrm{Cd}$ \\
\hline This study & $0.001-0.051 \pm 0.002$ & $0.01-4.01$ & $0.07-2.08$ & $0.01 \pm 0.001-3.24$ \\
$\begin{array}{l}\text { Similar studies } \\
\text { (Eludoyin \& Ogbe (2017)) }\end{array}$ & $\mathrm{NA}$ & $15.60-88.0$ & $18.40-80.30$ & $2.30-18.0$ \\
$\begin{array}{l}\text { Similar studies } \\
\text { (Okpanachi } \text { et al. }(2016))\end{array}$ & $\mathrm{NA}$ & $25.38-79.42$ & $5.48-33.28$ & $1.75-10.56$ \\
$\begin{array}{l}\text { FAO/WHO 2001, 2006, } \\
\text { 2007 }\end{array}$ & 2.3 & 40 & 0.3 & 0.2 \\
FEPA 1999 & NA & NA & NA & NA \\
NESREA 2011 & NA & NA & NA & NA \\
\hline
\end{tabular}

NA = Not available

In comparing the concentration of heavy metals in soil with the values of the concentration in cassava plants, the results indicate that the concentration of $\mathrm{Pb}(2.57 \pm 0.00 \mathrm{mg} / \mathrm{kg})$ and $\mathrm{Cr}(0.13 \pm 0.00)$ were higher in soil than in cassava plants for $\mathrm{Pb}(2.08 \pm 0.00 \mathrm{mg} / \mathrm{kg})$ and $\mathrm{Cd}(0.051 \pm 0.002 \mathrm{mg} / \mathrm{kg})$. The concentration of $\mathrm{Pb}$ and $\mathrm{Cr}$ in soil were 1.24 and 2.55 times higher than their corresponding values in cassava plants, respectively. In contrast, the values of the concentration of $\mathrm{Cu}(4.01 \pm 0.00 \mathrm{mg} / \mathrm{kg})$ and $\mathrm{Cd}(3.24 \pm 0.00 \mathrm{mg} / \mathrm{kg})$ in cassava roots were higher than their values in soil $(1.28 \pm 0.00 \mathrm{mg} / \mathrm{kg}$ and $0.26 \pm 0.00 \mathrm{mg} / \mathrm{kg}$ ). The concentrations of $\mathrm{Cu}$ and $\mathrm{Cd}$ in cassava roots were 3.13 and 12.46 times higher than their corresponding values in soils of the automobile waste dumpsite at Ohiya mechanic village. The soil is implicated for the concentrations of $\mathrm{Pb}$ and $\mathrm{Cr}$ in cassava plants while inherent ability of cassava roots to absorb and store $\mathrm{Cd}$ and $\mathrm{Cu}$ over time may be responsible for the higher concentration of $\mathrm{Cd}$ and $\mathrm{Cu}$ in cassava plants. The shallow root system of cassava plants might have facilitated the absorption of the heavy metals $(\mathrm{Cu}$ and $\mathrm{Cd})$ in soil solution and accumulation in cassava roots since $\mathrm{Cu}$ and $\mathrm{Cd}$ recorded the highest values of their concentrations in soil within $0-10$ and $21-30 \mathrm{~cm}$ depths, respectively. The rate of movement of heavy metal in plant tissues varies depending on plant organ, age and element involved (Kabata-Pemdias, 2000). The concentration of Cd increased from $0.01 \pm 0.001$ in cassava stem to $3.24 \pm 0.00 \mathrm{mg} / \mathrm{kg}$ in cassava root, which is well above the permissible limit (PL) of 0.2 $\mathrm{mg} / \mathrm{kg}$ set by Codex Alimentarius Commission (FAO/WHO, 2007) (Table 4) for vegetables and root crops. The values of the concentration of $\mathrm{Pb}$ increased from $0.07 \pm 0.000$ in cassava stem to $2.08 \pm 0.00$ $\mathrm{mg} / \mathrm{kg}$ in cassava root and the level is well above the permissible limit (PL) of $0.3 \mathrm{mg} / \mathrm{kg}$ set by Codex Alimentarius Commission (FAO/WHO, 2001). The utilization of cassava roots at the automobile waste dumpsite for man and animal consumption could be a route of entry of $\mathrm{Cd}$ and $\mathrm{Pb}$ in man as well as livestock that will be fed with the peels from such metal contaminated cassava roots. For instance, serious systemic adverse health consequences develop from excessive dietary accumulation of toxic metals in humans (Oliver 1997; Li et al., 2009). The prevalence of upper gastrointestinal cancer in the 
Van region of Turkey has been linked to metal pollution in soil, fruits and vegetables (Turkdogan et al., 2003). Soil and vegetables polluted with $\mathrm{Pb}$ and $\mathrm{Cd}$ in Romania significantly decreased human life expectancy by reducing the average age at death by 9-10 years (Carafa et al., 2009) while in the city of Kabwe, Zambia, mining and smelting operations led to widespread $\mathrm{Pb}$ and $\mathrm{Cd}$ contamination of soil (Fulekar and Jadia, 2009) and children living in the vicinity of a former smelter had high blood $\mathrm{Pb}$ levels in France (Pruvot et al., 2006) and Brazil (Bosso and Enzweiler, 2008). Lead and Cd are potential carcinogens and are associated with adverse effects on blood, kidneys, bone, as well as cardiovascular, and nervous system (Jarup, 2003).

Similarly, the dependent of wild animals such as Thryonomis swinderianus (grasscutter), Cricetomys gambianus (African giant pouched rat), Francolinus squamatus (Scaly francolin) among others on such contaminated cassava roots in farm at Ohiya mechanic village may lead to bio-magnification of $\mathrm{Cd}$ and $\mathrm{Pb}$ in the food chain with the concomitant effect of possible ecological imbalance in the natural environment. Copper increased from $0.01 \pm 0.000$ in cassava leaf to $4.01 \pm 0.00 \mathrm{mg} / \mathrm{kg}$ in root. The level of $\mathrm{Cu}$ in cassava plants is well below the permissible limit (PL) of $40 \mathrm{mg} / \mathrm{kg}$ (FAO/WHO, 2006) for vegetables and root crops. Chromium increased from $0.001 \pm 0.000$ in root to $0.051 \pm 0.002$ in cassava root but the level of $\mathrm{Cr}$ in cassava plants is well below the permissible limit (PL) of $2.3 \mathrm{mg} / \mathrm{kg}$ (FAO/WHO, 2006). The order of abundance of the four heavy metals tested in various parts of cassava plant in this study is as follows: $\mathrm{Cu}>\mathrm{Cd}>\mathrm{Pb}>\mathrm{Cr}$.

\subsection{Pearson correlation analysis between heavy metals in soil and plants}

The result of the Pearson correlation analysis of heavy metals in soil and plants is summarized in Table 5. The result show very strong positive relationship as well as strong negative relationship between heavy metals in soil and plants. For instance, very strong positive relationship exist between $\mathrm{Cu}$ in soil and $\mathrm{Cu}$ in plants $(\mathrm{r}=0.996, \mathrm{p}<0.05)$ and $\mathrm{Pb}$ in soil and $\mathrm{Pb}$ in plants $(\mathrm{r}=0.986, \mathrm{p}<0.05)$ which suggest that increase in $\mathrm{Cu}$ and $\mathrm{Pb}$ in soil might have resulted to their $(\mathrm{Cu}$ and $\mathrm{Pb})$ increase in cassava plants. Strong negative relationship exist between $\mathrm{Cr}$ in soil and $\mathrm{Cr}$ in plants $(\mathrm{r}=-0.686, \mathrm{p}<0.05)$ and $\mathrm{Cd}$ in soil and $\mathrm{Cd}$ in plants $(\mathrm{r}=-0.981, \mathrm{p}<0.01)$. However, there were strong positive relationship between $\mathrm{Cu}$ in soil with $\mathrm{Cr}$ in plants $(\mathrm{r}=0.997, \mathrm{p}<0.01), \mathrm{Cu}$ in soil with $\mathrm{Pb}$ in plants $(\mathrm{r}=0.970, \mathrm{p}<0.01)$ and $\mathrm{Cu}$ in soil with $\mathrm{Cd}$ in plants $(\mathrm{r}=0.997, \mathrm{p}<0.01)$ while strong negative relationship occurred between $\mathrm{Cd}$ in soil with $\mathrm{Cr}$ in plants $(\mathrm{r}=-0.990, \mathrm{p}<0.01), \mathrm{Cd}$ in soil with $\mathrm{Cu}$ in plants $(\mathrm{r}=-0.979, \mathrm{p}<0.01)$ and $\mathrm{Cd}$ in soil with $\mathrm{Pb}$ in plants $(\mathrm{r}=-0.987, \mathrm{p}<0.01)$.

Table 5: Correlation result between heavy metals in soil and heavy metals content in Manihot esculenta

\begin{tabular}{lcccccccc}
\hline & $\mathrm{Cr}$ (soil) & $\mathrm{Cu}$ (soil) & $\mathrm{Pb}$ (soil) & $\mathrm{Cd}$ (soil) & $\mathrm{Cr}$ (plant) & $\begin{array}{c}\mathrm{Cu} \\
\text { (plant) }\end{array}$ & $\mathrm{Pb}$ (plant) & $\begin{array}{c}\mathrm{Cd} \\
\text { (plant) }\end{array}$ \\
\hline $\mathrm{Cr}$ (soil) & 1 & -.445 & -.163 & -.002 & $-.686^{*}$ & $-.738^{*}$ & -.473 & $-.731^{*}$ \\
$\mathrm{Cu}$ (soil) & & 1 & $.926^{* *}$ & .341 & $.997^{* *}$ & $.996^{* *}$ & $.970^{* *}$ & $.997^{* *}$ \\
$\mathrm{~Pb}$ (soil) & & & 1 & $.576^{*}$ & $.904^{* *}$ & $.875^{* *}$ & $.986^{* *}$ & $.880^{* *}$ \\
$\mathrm{Cd}$ (soil) & & & & 1 & $-.990^{* *}$ & $-.979^{* *}$ & $-.987^{* *}$ & $-.981^{* *}$ \\
$\mathrm{Cr}$ (plant) & & & & & 1 & $.995^{* *}$ & $.961^{* *}$ & $.995^{* *}$ \\
$\mathrm{Cu}$ (plant) & & & & & & 1 & $.943^{* *}$ & $1.000^{* *}$ \\
$\mathrm{~Pb}$ (plant) & & & & & & & & 1 \\
$\mathrm{Cd}$ (plant) & & & & & & & & $.947^{* *}$ \\
\hline
\end{tabular}

*Correlation is significant at the 0.05 level (2-tailed); **Correlation is significant at the 0.01 level (2-tailed). 


\subsection{Conclusion}

The investigation of heavy metals contamination in soil and cassava plants at automobile waste dumpsite in Ohiya mechanic village, Abia State, Nigeria showed that artisanal activities generate wastes that release contaminants such as heavy metals. The values of highest concentration of heavy metals $(\mathrm{Cd}, \mathrm{Cu}, \mathrm{Pb}$ and $\mathrm{Cr}$ ) occurred within 0 to $30 \mathrm{~cm}$ depth. The heavy metals that are leached into the soil profile are taken up by cassava plant, especially the root. The values of the concentration of $\mathrm{Cd}$ in soil exceed maximum permitted level set by Codex Alimentarius Commission (FAO/WHO) while the values of the concentration of $\mathrm{Pb}$ and $\mathrm{Cd}$ in cassava plants exceed the permissible limit set by Codex Alimentarius Commission (FAO/WHO). The level of $\mathrm{Cd}$ in soil and $\mathrm{Pb}$ and $\mathrm{Cd}$ in cassava plant is a serious concern to man and animals' health as well as ecological processes taken place in the soil ecosystem. Therefore, it is recommended that rural farmers are informed the consequences of using such adjoining lands for farming activities. More so, efforts should be geared towards using wire gauze to fence round the dumpsite so that animals may not have access to the polluted soil and plants. Abia State Environmental Protection Agency and the leadership of the Automobile and Technician Association should monitor the activities of artisans to ensure strict compliance to industrial and environmental laws and regulations. For example, collection and recycling of spent oil and proper disposal of spent electrolyte to reduce heavy metal contamination in soil and biomagnification in flora and fauna.

\section{Acknowledgement}

We wish to acknowledge the Technologist that carried out the laboratory analysis of the soil and plant samples. We also acknowledge the Management of Ohiya mechanic village for allowing access to the automobile waste dumpsite.

\section{References}

Adebayo, A.J., et al. (2017). Delineation of heavy metals in soils from auto-mechanic workshops within Okitipupa, Ondo State, Nigeria. International Research Journal of Public and Environmental Health, 4 (7), pp. 136-147.

Adelekan, B.A and Abegunde, K.D. (2012). Heavy metals contamination of soil and groundwater at automobile mechanic villages in Ibadan, Nigeria. International Journal of the Physical Sciences, 6 (5), pp. 1045-1058.

Adrian, W.J. (1973). A comparison of a wet pressure digestionmethod with other commonly used wet and dry-ashing methods. Analyst, 98, pp. 213-216.

Ali, H., et al. (2013). Phytoremediation of heavy metals - concepts and applications. Chemosphere, 91(7), pp. 869-881.

American Public Health Association, APHA (1995). Standard Methods for the Examination of Water and Wastewater. 20th Edn., APHA, Washington, DC., USA.

Anegbe, B., Okuo, J.M., Atenaga, M., Ighodaro, A., Emina, A., et al. (2018). Distribution and speciation of heavy metals in soils around some selected auto repair workshops in Oghara, Delta State, Nigeria. International Journal of Environment, Agriculture and Biotechnology, 3(2), pp. 574-584.

Anyanwu, C.N., et al. (2015). Sustainability of cassava (Manihot esculenta Crantz) as industrial feedstock, energy and food crops in Nigeria. Renewable Energy, 81, pp. 745-752.

Arora, M., Kiran B., Rani, S., Rani, R. Kaur, K., et al. (2008). Heavy metal accumulation in vegetables irrigated with water from different sources. Food Chemistry, 111, pp. 811-815.

Bosso, S.T. and Enzweiler, J. (2008). Bioaccessible lead in soils, slag and mine wastes from an abandoned mining district in Brazil. Environmental Geochemistry and Health, 30, pp. 219-229. 
Carafa, A.M., et al. (2009). Assessment of heavy metals transfer from a moderately polluted soil into the edible parts of vegetables. Journal of Food, Agriculture and Environment, 7, pp. 683-688.

Davila A.F., et al. 2006. Mapping the sources of urban dust in a coastal environment by measuring magnetic parameters of Platanus hispanica leaves. Environmental Sciences and Technology, 40(12), pp. $3922-3928$.

Demie, G. (2015). Analyzing soil contamination status in garage and auto mechanical workshops of Shashemane City: implication for hazardous waste management. Environmental System Research, 4, pp. 15-23.

Droppelmann, K., Günther, P., Kamm, F., Rippke, U., Voigt, C., et al. (2018). Cassava, the $21^{\text {st }}$ century crop for smallholders? Exploring innovations along the livelihood value chain nexus in Malawi. Centre for Rural Development (SLE) Berlin, SLE Publications Series, S274. http://edoc.huberlin.de/bitstream/handle/18452/19887/SLE274\%20Cassava,\%20the\%2021st\%20century\%20crop\% 20for\%20smallholders.pdf?srquence $=1$ (Accessed $9^{\text {th }}$ October 2019).

Eludoyin, O.S. and Ogbe, O.M. (2017). Assessment of heavy metal concentrations in pawpaw (Carica papaya Linn.) around automobile workshops in Port Harcourt metropolis, Rivers State, Nigeria. Journal of Health Pollution, 14, pp. 48-61.

European Commission Director General Environment, ECDGE (2010). Heavy Metals and Organic Compounds from Wastes Used as Organic Fertilizers. Final Rep., July. WPA Consulting Engineers Inc. $\begin{array}{lllll}\text { Ref. Nr. } & \text { TEND/AML/2001/07/20, } & \text { 73-74. }\end{array}$ http://ec.europa.eu/environment/waste/compost/pdf/hm_finalreport.pdf.

Falahi-Ardakani, A. (1984). Contamination of environment with heavy metals emitted from automotives. Ecotoxicology and Environmental Safety, 8, pp. 152-161.

FAO/WHO (2001). Food additives and contaminants. Joint FAO/WHO Food Standards Program, ALINORM 01/12A: 1-289.

FAO/WHO (2006). Guidelines for assessing Quality of Herbal Medicines with Reference to Contaminants and Residues, World Health Organization, Geneva, Switzerland.

FAO/WHO (2007). Joint FAO/WHO Food Standard Programme Codex Alimentarius Commission 13th Session. Report of the Thirty Eight Session of the Codex Committee on Food Hygiene. Houston, TX, ALINORM 07/30/13.

Federal Environmental Protection Agency (FEPA) (1991). Guidelines and Standards for Environmental Pollution in Nigeria.

Fulekar, M.H. and Jadia, C.D. (2009). Phytoremediation of heavy metals: Recent techniques. African Journal of Biotechnology, 8, pp. 921-928.

Garcia, G., et al. (2004). Performance of Piptatherum miliaceum (Smilo grass) in edaphic $\mathrm{Pb}$ and $\mathrm{Zn}$ phytoremediation over a short growth period. International Bioremediation and Biodegradation. 54 (23), pp. 245-250.

Goodman, G.T. and Robert, T.M. (1971). Plants and soils as indicators of metals in the air. Nature, 231, pp. 287-292.

Hashem, M.A., et al. (2017). Hair burning and liming in tanneries is a source of pollution by arsenic, lead, zinc, manganese and iron. Environmental Chemistry Letters, 15(3), pp. 501-506.

Idugboe, S.O, et al. (2014). Soil pollution in two auto-mechanic villages in Benin City, Nigeria. IOSR Journal of Environmental Science, Toxicology and Food Technology, 8(1), pp. 9-14.

Iwegbue, C.M.A., et al. (2007). Characteristic levels of heavy metals in soil profiles of automobile mechanic waste dumps in Nigeria. Environmentalist, 26, pp. 123-128. 
Jarup, L. (2003). Hazard of heavy metal contamination. British Medical Bulletin, 68 (1), pp. 167-182. Kabata-Pendias, A. (2000). Trace elements in soils and plants, CRC Press, Boca Raton.

Keay, R.W.J. (1959). An outlines of Nigeria vegetation. $3^{\text {rd }}$ ed. Government Printer, Lagos, Nigeria.

Lawal, N.S., et al. (2019). Characteristics and waste management practices of cassava-based processing clusters in Ibadan Oyo State, Nigeria. Nigerian Research Journal of Engineering and Environmental Sciences, 4(2), pp. 658-666.

Li, Z., et al. (2009). Health risk from heavy metals via consumption of food cops in the vicinity of Dabaoshan mine, South China. Science of the Total Environment, 407, pp. 1551-1556.

Luter, L., et al. (2011). Heavy metals in soils of auto- mechanic shops and refuse dumpsites in Makurdi, Nigeria. Journal of Applied Science Environmental Management, 15(1), pp. 207-210.

National Population Commission of Nigeria (NPC) (2006). Population and Housing Census Result. NPC, Lagos, Nigeria.

NESREA (2011). "1 ${ }^{\text {st }}$ Eleven Gazetted Regulations Federal Republic of Nigeria Official Gazette”.

Nwachukwu, M.A., et al. (2010). Assessment of heavy metal pollution in soil and their implications within and around mechanic villages. International Journal of Environmental Science and Technology, 7(2), pp. 347-358.

Nyarko, H.D., et al. (2019). Effect of petroleum fuels and lubricants on soil properties of auto-mechanic workshops and garages in Cape Coast metropolis, Ghana. Journal of Applied Sciences and Environmental Management, 23(7), pp. 1287-1296.

Ogbonna, P. C. and Okezie, N. (2011). Heavy metals and macronutrients content of roadside soil and vegetation in Umuahia, Nigeria. Journal of Terrestrial and Aquatic Environmental Toxicoloy, 5(1), pp. 35-39.

Ogbonna, P.C. and Okeke, V. (2011). Heavy metal level of soil and gmelina plantation in Umuahai, Nigeria. Terrestrial and Aquatic Environmental Toxicology, 5(1), pp. 31-34.

Ogbonna, P.C., et al. (2012). Bioaccumulation of nutrients and heavy metals in plants at a coal mine. Terrestrial and Aquatic Environmental Toxicology, 6(2), pp. 127-131.

Ogbonna, P.C., et al. (2013). Distribution of heavy metals in soil and accumulation in plants at an agricultural area of Umudike, Nigeria. Chemistry and Ecology, 29(7), pp. 595-603.

Ogbonna, P.C., et al. (2018a). Soil chemical characteristics in wet and dry season at Iva long wall underground mined site, Nigeria. Nigerian Journal of Environmental Sciences and Technology, 2(1), pp. 96-107.

Ogbonna, P.C., et al. (2018b). Determination of heavy metals in sawdust particles, distribution in soil and accumulation in plants at Ahiaeke timber market. Nigerian Journal of Environmental Sciences and Technology, 2(2), pp. 160-170.

Ogbonna, P.C., et al. (2018c). Determination of seed bank depth and viability of Monodora myristica at Ohiya in Umuahia South Local Government Area, Abia State, Nigeria. Journal of Sustainable Agriculture and Environment, 17(1):75-86.

Ogbonna, P.C., et al. (2019). Determination of heavy metal and macronutrients in Hyperiodrilus africanus (Earthworm) and Scolopendra cingulate (Centipede) at coal mining sites in Enugu State, Nigeria. Nigerian Research Journal of Engineering and Environmental Sciences, 4(1), pp. 341-351.

Ogunkolu, A.B., et al. (2019). Assessment of heavy metal contamination of soil around auto mechanic workshops in Anyigba, Kogi State. Confluence Journal of Environmental Studies, 13(1), pp. 79-89. 
Oguntimehin, I. and Ipinmoroti, K. (2008). Profile of heavy metals from automobile workshops in Akure, Nigeria. Journal of Environmental Science and Technology, 1(1), pp. 19-26.

Ojekunle Z. O., et al. (2014). Effectiveness of neem, cashew, and mango trees in the uptake of heavy metals in mechanic village. Merit Research Journal of Environmental Science and Toxicology, 2(8), pp. 185-190.

Okpanachi, C.B., et al. (2016). Assessment of selected heavy metal level in soil and maize (Zea mays) plant within the vicinity of auto mechanic workshops in Gwagwalada, Abuja, Nigeria. International Journal of Plant \& Soil Science, 12(2), pp. 1-11.

Oliver, M.A. (1997). Soil and human health: A review. European Journal of Soil Science, 48, pp. 573592.

Olutosin, A.O and Barbara, S. (2019). Cassava, a $21^{\text {st }}$ century staple crop: How can Nigeria harness its enormous trade potentials? Acta Scientific Agriculture, 3(8), pp. 194-202.

Onder, S. and Dursun, S. (2006). Air borne heavy metal pollution of Cedrus libani (A. Rich.) in city center of Konya (Turkey). Atmospheric Environment, 40, pp. 1122-1133.

Organization for Economic Cooperation and Development (OECD) (2004). Guideline for the Testing of Chemicals, Earthworm reproduction Test (Eisenia fetida/Eisenia andrei). No. 222, Paris.

Owoso, J., et al. (2017). Heavy metal contamination of soil and groundwater by artisanal activities in Lagos metropolis, Nigeria. International Journal of Scientific and Engineering Research, 8(4), pp. 1344-1349.

Oyelola,O. T., et al. (2009). Health implications of solid waste disposal: case study of Olusosun dumpsite, Lagos, Nigeria. International Journal of Pure and Applied Sciences, 3 (2), pp. 1-8.

Oyeyinka, S.A., Ajayi, O.I., Gbadebo, C.T., Kayode, R.M.O., Karim, O.R. et al. (2019). Physiochemical properties of gari prepared from frozen cassavaroots. LWT-Food Science and Technology, 99, pp. 594-599.

Pam, A.A., et al. (2013). Evaluation of heavy metals in soils around auto mechanic workshop clusters in Gboko and Makurdi, central Nigeria. Journal of Environmental Chemistry and Ecotoxicokogy, 5(11), pp. 298-306.

Pruvot, C., et al. (2006). Heavy metals in soil, crops and grass as a source of human exposure in the former mining areas. Journal of Soils and Sediments, 6, pp. 215-220.

Radwan, M.A. and Salama, A.K. (2006). Market basket survey for some heavy metals in Egyptian fruits and vegetables. Food Chemistry and Toxicology, 44, pp. 1273-1278.

Sakan, S.M. and Dordevic, D.S. (2010). Evluation of heavy metal contamination in sediments using the method of total digestion and determination of the binding forms - Tisa River Basin, Serbia. Journal of Environmental Science and Health Part A, 45, pp. 783-794.

Steel, R.G.D. and Torrie, J.H. (1980). Principles and procedures of statistics: A biometric approach, McGraw-Hill, New York, p. 633.

Sukkariyah, B.F., et al. (2005). Recovery and distribution of biosolids-derived trace metals in a Esnaola, M.V., A. Bermond, and E. Millan. 2000. Optimization of Davidson clay loam soil. Journal of Environmental Quality, 34, pp. 1843-1850.

Türkdogan, M.K., et al. (2003). Heavy metals in soil, vegetables and fruit in the endemic upper gastrointestinal cancer region of Turkey. Environmental Toxicology and Pharmacology, 13(3), pp. 175179. 
Wilberforce, J.O.O. (2016). Accumulation of toxic metals in soils of different sections of mechanic village Abakaliki, Nigeria and their health implications. American Chemical Science Journal, 11(1), pp. 1-8.

Zainuddin, I.M., Fathoni, A., Sudarmonowati, E., Beeching, J.R., Gruissem, W., et al. (2018). Cassav post-harvest physiological deterioration: From triggers to symptoms. Postharvest Biology and Technology, 142, pp. 115-123.

Zechmeister, H.G., et al. (2005). Estimation of element deposition derived from road traffic sources by using mosses. Environmental Pollution, 138, pp. 238-249.

\section{Cite this article as:}

Ogbonna P.C., Osim O.O. and Biose E., 2020. Determination of Heavy Metal Contamination in Soil and Accumulation in Cassava (Manihot Esculenta) in Automobile Waste Dumpsite at Ohiya Mechanic Village. Nigerian Journal of Environmental Sciences and Technology, 4(1), pp. 54-69. https://doi.org/10.36263/nijest.2020.01.0173 